\title{
Metal Highlights
}

\section{METALS SOLUTIONS}

\section{ThyssenKrupp VDM offers fuel cells improved material}

ThyssenKrupp VDM, together with the Jülich Research Center, has developed Crofer $22 \mathrm{H}$, a material for solid oxide fuel cells (SOFC). The new material can be used to produce lightweight fuel cell stacks, e.g. for use in vehicles. "A particular emphasis of our work on Crofer $22 \mathrm{H}$ was to develop a commercial-scale production process" says Dr. Jutta Klöwer, head of research and development at ThyssenKrupp VDM. "As a result, we can now supply a lower-cost alloy with superior properties to steel for use in fuel cell interconnects". The material is suitable for largescale energy supply systems, small decentralized household units and automotive applications.

In fuel cells, the material is used in the so-called interconnects - plates that connect the individual cells into an efficient stack. For this it needs to display numerous characteristics such as electrical conductivity, corrosion resistance and mechanical strength; it must also be readily formable and have no adverse effects on the cell. Crofer $22 \mathrm{H}$ contains between 20 and $24 \%$ chromium and other alloying elements such as tungsten, niobium, titanium and lanthanum. The new material is characterized by high corrosion resistance at temperatures up to $900{ }^{\circ} \mathrm{C}$, good electrical conductivity of the oxide layer, and high mechanical strength at operating temperature.

A further advantage is its thermal expansion, which matches that of the ceramic materials used in the cell. This prevents mechanical stresses between the two materials that could damage the ceramics. In addition to Crofer $22 \mathrm{H}$, further materials from ThyssenKrupp VDM are used in fuel cells. For example, high-temperature nickel alloys feature in other SOFC parts such as heat exchangers and reformers.

\section{Nippon Steel develops six-inch diameter silicon carbide single crystal wafer}

Nippon Steel Corporation has developed, at the Advanced Technology Research Laboratories of its Technical Development Bureau, six-inch diameter silicon carbide ("SiC") single-crystal wafer, meant for mass production and spread of high-performance-power semiconductor devices.

SiC wafer, as compared with silicon wafers being used in the manufacture of diode, transistor and other semiconductor devices, is capable of suppressing the power-conversion loss to less than half when used in various electronic devices. It is also successful in both high-voltage

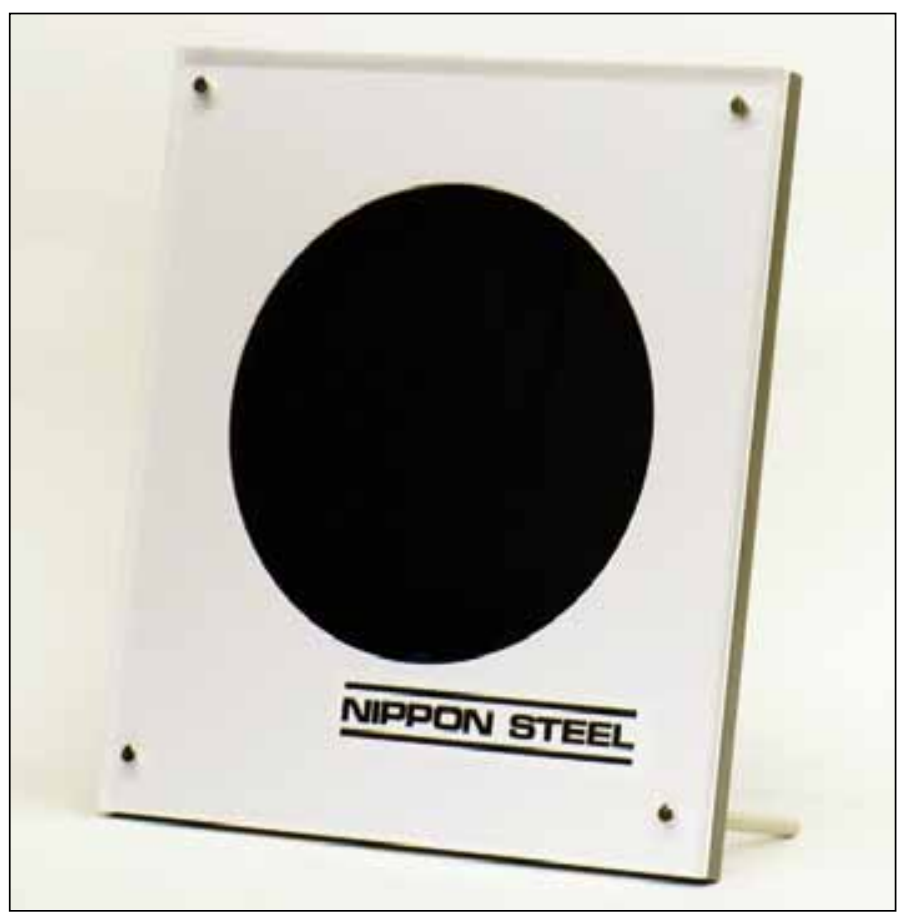

The outcoming of 6-inch wafer must allow to further extend applications to automobiles, rapid-transit railways and other areas.

and heat resistance properties, making it suitable for high-voltage, hightemperature uses in photovoltaic power generation, automotive (EV, HEV, etc.), and other applications of power electronics.

$\mathrm{SiC}$ wafers now on the market predominantly have 3-inch and 4-inch diameters, and semiconductor-manufacturers' development and commercialization of semiconductors are being made based upon the availability of such SiC wafers. Six-inch SiC wafer is expected to increase the efficiency of $\mathrm{SiC}$ device production and to decrease the cost of device manufacture. The outcoming of 6-inch wafer must also make it possible to manufacture large-area device for controlling larger current and higher voltage, thus affording to further extend applications to automobiles (EV/HEV, etc.), rapidtransit railways, and other broader areas.

\section{INDUSTRY CONTRACTS}

\section{Steel structure contract for Ruukki in Sweden}

Ruukki has signed a contract worth around 5 million $€$ for total delivery of a new mail terminal to be built in Hallsberg, Central Sweden. The new building will total around 30000 square metres. The order was placed with Ruukki by NCC Construction Sverige AB, the main contractor in the project. 


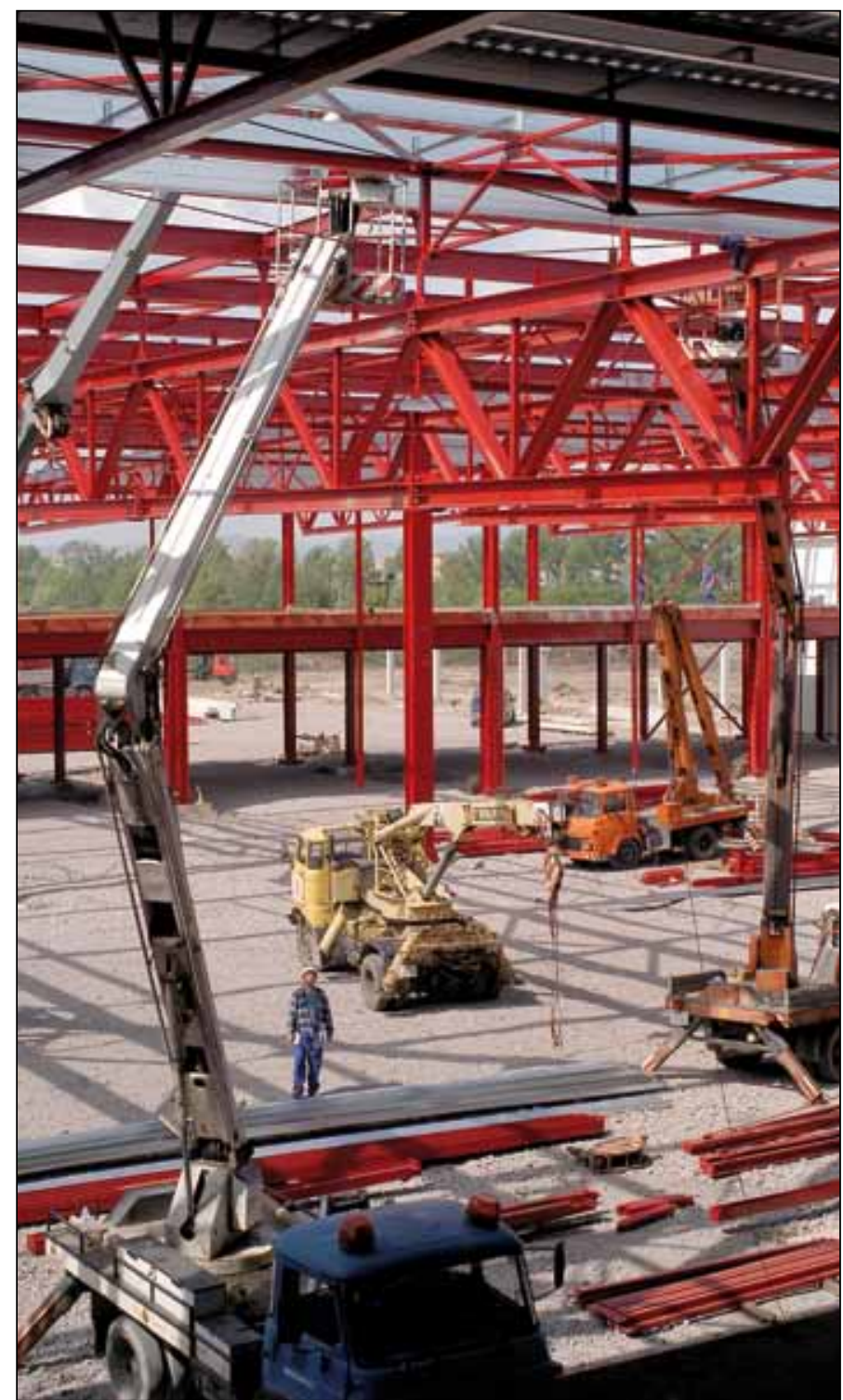

Ruukki will supply steel frame, façades and load-bearing roof structures.

Ruukki's total delivery comprises the steel frame, façades and loadbearing roof structures. Ruukki is also responsible for structural design and installation.

Sweden Post plans to make Hallsberg in Central Sweden the hub of mail sorting and to switch from air cargo to railway freight. The building will also serve as a train loading and discharging terminal.

Installation work is expected to last about six months. The building is scheduled for completion during 2012. The frame will be made at Ruukki's plant in Peräseinäjoki, the façade panels in Alajärvi and the roof profiles in Vimpeli, Finland. The contract also includes delivery and installation of the hollow core slabs and plinth elements for the building.

\section{Posco wins domestic and overseas orders}

Posco, South Korea, has secured the full-order for the rolled steel required for the construction of Lotte World Tower. With 123 floors planned for above-ground, and six below, Lotte World Tower, to be built in Jamsil, Seoul, is to be the world's second tallest building, behind UAE's Burj Khalifa. The construction is planned to be completed by 2015 , using 40000 tons of rolled steel including regular and thermomechanical control processed (TMCP) steel.

Posco worked with List Steel Structure Lab to propose the adoption of extra thick plates including the $80 \mathrm{~mm}$ high-performance grade steel and $120 \mathrm{~mm}$ thick regular plates, and steel column flat plate structure as well as module-type steel piping.

Other contracts won by Posco include:

- A plant automation system at a CSP steel mill in Brazil; the integrated mill, is being built in partnership with iron ore supplier Vale (Brazil), Dongkuk Steel and Posco. Posco ICT is to build the plant automation system required for the blast furnace, raw material, sintering, coke manufacturing, steel making and continuous casting process for the mill, including electricity, instrumentation and computer control systems.

- A waste-to-energy $25 \mathrm{MW}$ power plant project in Haiti, which is due to incinerate waste produced in urban areas adjacent to Port-au-Prince, and generate electric power.

\section{Sumitomo selected for wind farm project in South Africa}

Sumitomo Corporation (Japan) and its local partners have been selected as a preferred bidder for a $100 \mathrm{MW}$ wind farm project. The South African government seeks to procure a total of $3.725 \mathrm{MW}$ of electricity from renewable energy sources by the end of fiscal year 2014. A total of roughly 20 billion yen (approximately 190 million $€$ ) will be invested to construct the Dorper wind farm, which will consist of $402.5 \mathrm{MW}$ wind turbines extending over a vast pastured area. The electricity generated will be sold under a 20-year power purchase agreement to be concluded with Eskom Holdings SOC Limited, a state-owned utility company, with a payment guarantee from the DOE.

In Japan, Sumitomo currently manages two wind farms producing a total of $36 \mathrm{MW}$ of electricity. Outside Japan, it operates a $50 \mathrm{MW}$ wind farm in China's Inner Mongolia autonomous region as well as a $120 \mathrm{MW}$ wind farm in Texas. Furthermore, in 2011, Sumitomo Corporation took a stake in the 845 MW Caithness Shepherds Flat wind farm project as its second investment in the wind farm in the United States. Construction work on Shepherds Flat is currently underway as planned, with completion set for next year. 


\section{Essar Projects bags water pipeline contract}

Essar Projects, part of the Essar Group was awarded the (approximately) 44 million $€$ contract from Gujarat Water Infrastructure Limited (GWIL) to engineer, procure, construct and commission a $2300 \mathrm{~mm} \times 51 \mathrm{~km}$ water pipeline system.

This is part of the bulk water transmission system project being implemented by the Gujarat Government. The project is scheduled for completion in 2013. It is one of the eight packages of Sardar Sarovar Narmada Canal-based drinking water supply project, which aims at supplying water to all the rural and urban areas of the seven districts of Saurashtra, Kachchh region and parts of Ahemdabad, Sabarakantha, Mehsana districts of North Gujarat and Panchmahals.

\section{Tata Steel secures profiled steel plate order for Siemens wind towers}

Tata Steel has secured a contract from Siemens Wind Power to supply 25000 tons of profiled steel plate for wind towers. The order is the largest to date for the steel company's dedicated wind tower hub in Scunthorpe, England. Tata Steel will be delivering 25000 tons of profiled plate (cut into the desired shape) between April and September 2012. The steel will be used to build about 150 onshore wind turbine towers. Tata Steel has already supplied Siemens Wind Power with 6000 tons of steel plate for similar developments in the UK and Europe.

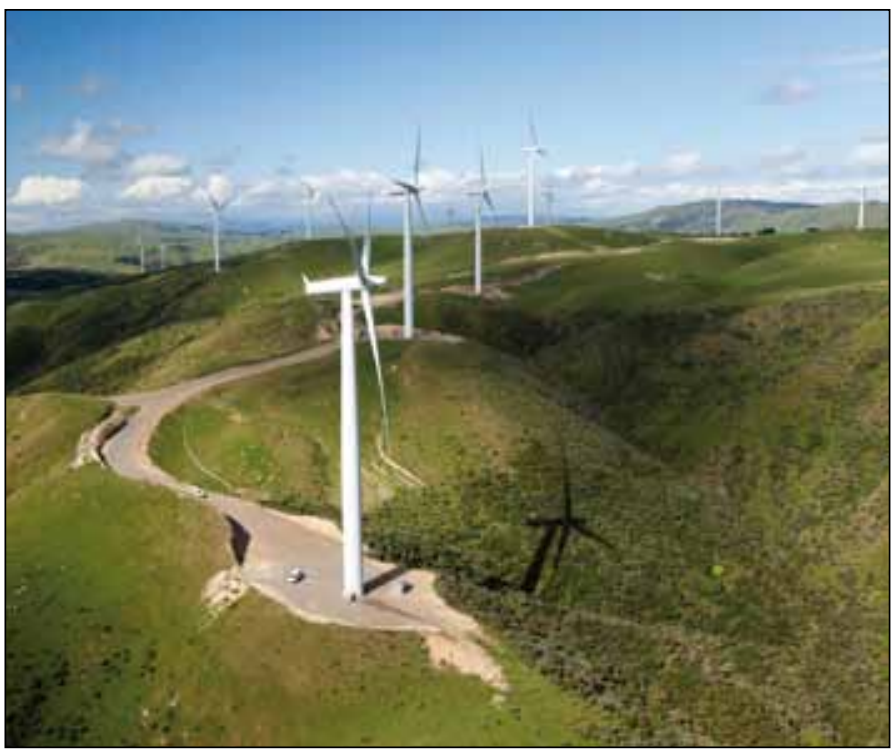

25000 tons of profiled plate will be used to build about 150 onshore wind turbine towers. Photo courtesy of Siemens
Steel plate will be manufactured at Tata Steel's plate mills in Scunthorpe, and Dalzell, in Motherwell, Scotland, before being cut to size and edge-profiled at the company's dedicated wind tower hub in Scunthorpe. The steel will be delivered to a fabricator which will form the plate into round sections before they are welded together to form the turbine tower.

Tata Steel's wind tower hub in Scunthorpe was established in 2010 to process and distribute steel plate to manufacturers of wind turbine towers. It can deliver up to 200000 tons annually.

\section{TMK makes first shipment of vacuum insulated tubing to Gazprom}

Producer of tubular products for the oil and gas industry TMK, has made its first shipment of vacuum insulated tubing (VIT) to Gazprom for the use in the Bovanenkovskoye gas condensate field on the Yamal Pensinsula.

The total volume of the pilot shipment was 722 running meters. TMK specialists assisted with the first running of the pipe column which included VIT as its upper section. Tubing with TMK FMT premium connections was also successfully run in the lower section of the string.

Other major Russian oil and gas companies have also expressed interest in VIT. In 2012, TMK plans to manufacture and ship approximately 9000 running meters of this product.

"TMK has become a pioneer in manufacturing vacuum insulated tubing in Russia", said Alexander Shiryaev, TMK CEO. "The importance of this type of pipe for oil and gas companies is increasing in line with growing hydrocarbon production in harsh climatic conditions. The use of VIT in such fields allows for considerable improvement in the energy efficiency of well development and ensures the safety and environmental soundness of production. The successful well run of the first VIT manufactured for Gazprom also represents an important step in the strategic partnership of our two companies".

\section{voestalpine secures car parts contract}

The Automotive division of the voestalpine group has concluded its largest single contract to date, with a leading European car manufacturer. The order volume amounts to around 700 million $€$. As a result, the voestalpine group will produce sophisticated automotive components in countries such as China and the USA for the first time. "The roughly 100 million $€$ of investment, above all in China and the USA, is part of our 


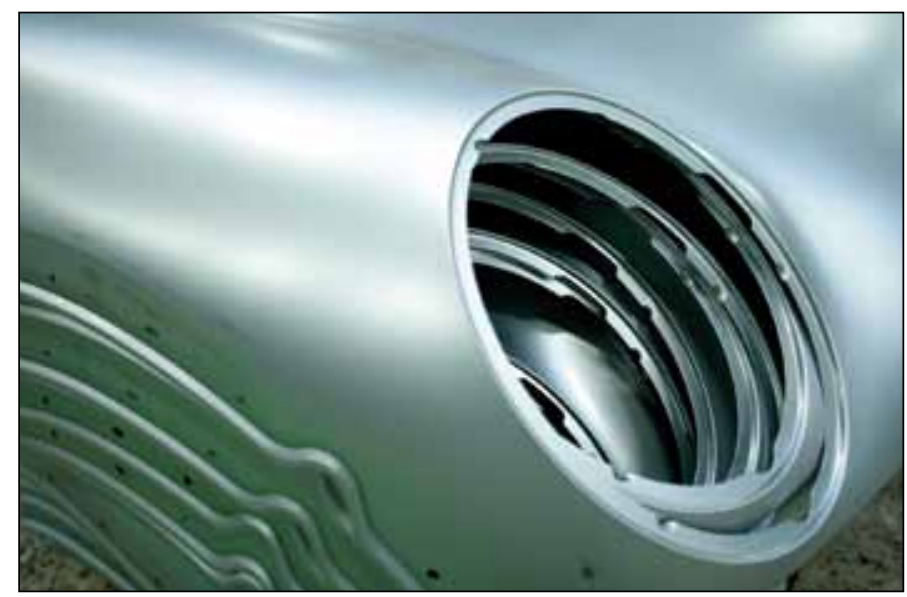

Components will involve the "phs-ultraform" hot-dip galvanized auto body steel.

globalisation strategy. We follow European car manufacturers into their future markets where we significantly expand our presence", explains Wolfgang Eder, Chairman of the Management Board.

In addition to a comprehensive package of high-tensile, sophisticated security components, the agreement includes replacement and assembly parts for a new generation of models. Exisiting voestalpine production sites will be expanded and new sites established in order for production to take place in the immediate vicinity of each automotive plant.

All the key components produced for this contract will involve the product "phs-ultraform". Phs-ultraform is hot-dip galvanized auto body steel, developed by voestalpine and formed during the new "indirect press-hardening" process. This has required the construction of a such press-hardening facility, for serial production in Germany. The components are initially cold-pressed before being heated to $900{ }^{\circ} \mathrm{C}$ and then subsequently hardened by cooling down to $70^{\circ} \mathrm{C}$ within just a few seconds. The corrosion-protected components manufactured using this process are both lighter and stronger.

\section{Valinox Nucléaire awarded first contract for steam generators of $1300 \mathrm{MW}$ power plants}

Vallourec announces that Valinox Nucléaire, its subsidiary specialising in the production of tubes for nuclear power plants, has been awarded a contract by Areva to manufacture tubes for the steam generators of two reactors of $1300 \mathrm{MW}$. This contract relates to the EDF programme announced in September 2011, to gradually replace large components of its $1300 \mathrm{MW}$ power plants, which attributed the building of new steam generators for 11 reactors to Areva and Westinghouse.
The steam generators feature an inner circuit made up of 122 kilometres of nickel-alloy tubes designed to create steam, which is then used to produce electricity via a high-power turbine.

Valinox Nucléaire is a wholly-owned subsidiary of Vallourec. In 2011, Valinox Nucléaire completed an extension to its production capacity at its plant in Montbard (Burgundy, France), multiplying its production capacity by close to 3 . Valinox Nucléaire today employs 500 people in Montbard.

\section{PLANTS AND EQUIPMENTS}

\section{Severstal commissions second color-coating line for hot dip rolled products}

Severstal's steel production unit, the Cherepovets steel mill, has commissioned its second color-coating line (CCL-2). The total investment in the second line is more than 2.5 billion roubles (78.1 million \$). The new line must double the plant's output of coated hot dip rolled products, in line with Severstal's stated strategic focus on increasing production.

CCL-2 is designed to produce up to 200000 tons per annum of coated hot dip rolled products measuring from $0.3 \mathrm{~mm}$ to $2.0 \mathrm{~mm}$ in thickness and up to $165 \mathrm{~cm}$ in width.

Alexander Grubman, CEO of Severstal Russian Steel, commented: "With the new line coming on-stream, our annual production of prepainted galvanized iron will double to reach 400000 tons per year, and we anticipate the company's share in the Russian polymer-coated galvanized steel market will increase above $20 \%$ ".

The new line includes an air reburning plant to reburn furnace offgases (polymer coating solvent vapor mixture) at $900{ }^{\circ} \mathrm{C}$, meant to improve its energy efficiency. It will use semi-finished rolled stock from the Cherepovets Steel Mill's new continuous hot dip galvanizing unit (commissioned in December 2010) and the hot dip rolled products line at Severgal.

The properties of the rolled products and the equipment capable of applying any polymer coating to metal must enable Severstal to fulfill more orders for pre-painted galvanized iron. Specifically, Severstal will be able to supply a wider range of products to sheeting manufacturers and manufacturers of white goods and other household appliances.

The main production equipment for the new line was supplied by SMS Siemag (Germany) and was designed by Severstal-Proekt. Severstal's 
subsidiaries: Metallurgremont, Spetsmontazh and Severstal-Promeservis were also involved in the project.

\section{Siemens VAI Metals Technologies to modernize Riva's medium-section mill}

Siemens VAI Metals Technologies has received an order from Riva Acciaio to modernize the roughing stand of the medium-section mill in Sellero, Italy. The scope includes the complete process and mechatronics packages for the blooming stand, the electric and automation systems and the erection.

Riva Acciaio's medium-section mill in Sellero, in the province of Brescia, was supplied by Siemens in 1996. It has an annual capacity of around 250000 tons and is designed to produce squares, flat bar and U-sections with widths of up to 340 millimeters and round bar with diameters of up to 160 millimeters.

For the roughing mill of the rolling line, Siemens is to supply a reversing red ring blooming stand and a reduction group, the roller tables and equipment for shifting and rotating the incoming blooms. The blooming stand enables symmetrical roll gap control and is equipped with a quick-change device for changing rolls, which allows operator to quickly switch the rolling line to a different final product.

The scope of supply also encompasses the main and auxiliary drives, including the motors and the basic automation. Siemens will install a CCTV system and will be responsible for supervising installation and commissioning. The modernization is to be completed in the second half of 2012.

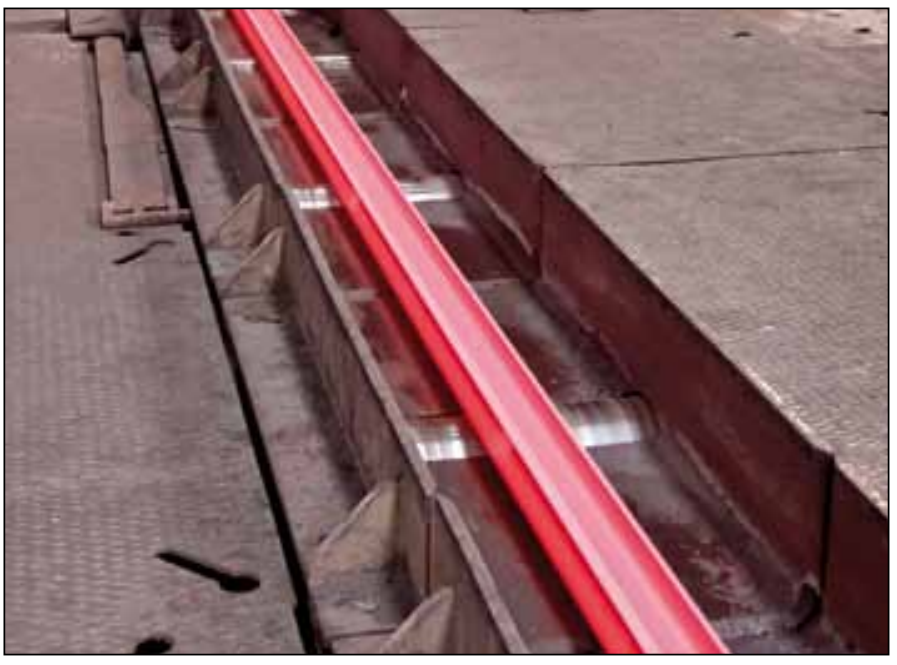

Section rolled on a rolling mill for medium-sized products from Siemens.
Riva Acciaio is a wholly owned subsidiary of Riva Fire S.p.A. The Riva Group has more than 35 production sites in Europe, North Africa, and Canada and produced around 14 million tons of raw steel in 2010.

\section{Constellium completes stretcher project at Ravenswood facility}

Constellium has commissioned its new stretcher at its facility in Ravenswood, West Virginia, US. The stretcher is a critical piece of equipment, unique to the Ravenswood facility, and allows Constellium to provide aluminum plate for aerospace and defense applications. The re-build represents a 46 million \$ investment.

\section{NLMK expands slab casting capacity}

The first slabs have been cast at Novolipetsk's (NLMK's main production site in Lipetsk) newly revamped 1 mtpy vertical continuous casting machine (CCM-3). Following the revamp, CCM-3 capacity increased by 300 ktpy due to higher casting rates and shorter periods between repairs. Product mix capabilities have been expanded, with new equipment allowing slab thickness of up to $315 \mathrm{~mm}$ and steel quality has been improved due to increased process automation.

The 90 million $€$ project is part of the second stage of NLMK's Technical Upgrade Program, which, alongside other activities, is aimed at increasing steel output from 9 to 12.4 mtpy at NLMK's Lipetsk site.

\section{Alcoa expands aluminum lithium capabilities}

Alcoa is expanding its aluminum lithium capacity and capabilities at three locations around the world to respond growing demand in the aerospace market. The alloys, introduced last year and now patented, allow airframers to build lighter and lower-cost airplanes vs. composite alternatives.

The new alloys are due to provide strength-to-weight performance combined with better stiffness and corrosion resistance. The alloys are used in extrusions, forgings, sheet and plate applications across aircraft structures, including airplane wings and fuselage elements.

The largest of the aluminum lithium capacity expansions is a greenfield facility to be constructed adjacent to Alcoa's Lafayette, Indiana plant. When completed the facility will produce more than 20000 tons of aluminum lithium and be capable of casting round and rectangular ingot for rolled, extruded and forged applications. Alcoa plans to invest more 
than 90 million \$ in this facility. Initial work on the new Lafayette facility has already begun and is expected to produce its first aluminum lithium by the end of 2014 .

"In addition to producing a wide range of billet sizes up to 33-inches in diameter, we will also be able to produce slab capable of producing wing skin plate and fuselage sheet for any current or planned commercial air program", said Eric Roegner, President of Alcoa Forged and Extruded Products.

\section{= Chemcoater on ThyssenKrupp's coil-coating line 3 in Siegerland now in operation}

The new chemcoater on coil-coating line 3 at the Siegerland location of ThyssenKrupp Steel Europe must improve significantly workflows on the coil-coating line - where paint and film coatings are applied to thin steel sheet.

The chemcoater is a piece of equipment used to apply chemical substances to galvanized flat carbon steel. These substances are waterbased media with additives that pretreat the steel and increase the corrosion protection of subsequent paint and film coatings. The chem-

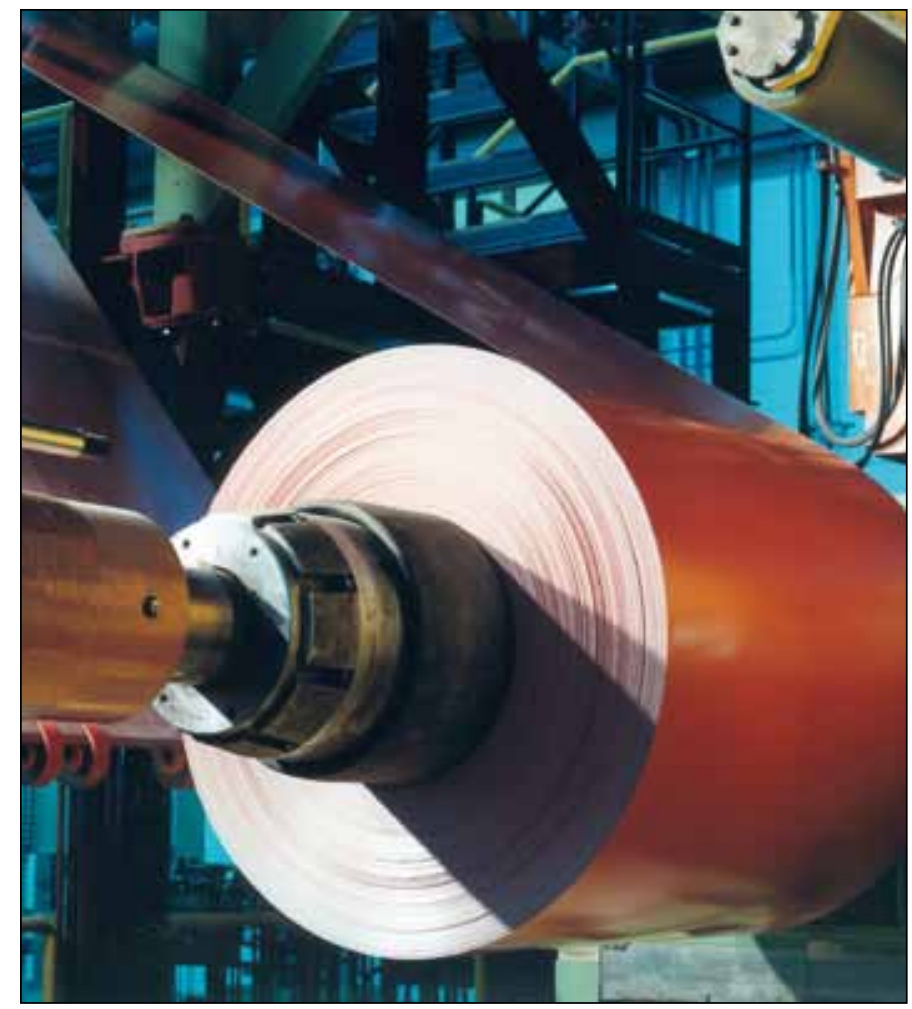

The paint- and film-coated steel is supplied in the form of coil, slit strip and cut-to-length sheets. coater carries out chemical pretreatment processes required for the subsequent painting process. A total of three different chemicals can be applied to the sheet via rolls. The unit operates on the basis of a reuse process so that no wastewater is produced except in the subsequent rinsing operation. "This six million euro investment virtually eliminates the need for chromium-based corrosion-protection pretreatments for organically coated parts", says team coordinator Ralf Wittkowski. "By using zinc-magnesium hot-dip coated starting material, we achieve better corrosion protection results with thinner zinc coatings. Water consumption is also reduced: by using two five-stage cascade rinses we have reduced the amount of water we need by 8000 liters per hour".

The planning phase for the modernization of coil-coating line 3 began three years ago, and the project was finally implemented in 2011. During the three-week shutdown when the chemcoater was installed, maintenance and cleaning work to ensure defect-free operation of the line was carried out. The paint- and film-coated steel produced on coilcoating line 3 is supplied in the form of coil, slit strip and cut-to-length sheets for use in the construction, appliance, garage door and auto industries.

\section{TMK and Lukoil sign agreement on pipe supplies}

Producer of tubular products for the oil and gas industry TMK, and oil and gas company Lukoil, have signed an agreement on pipe supplies for 2012.

Under the agreement, TMK guarantees to supply $100 \%$ of pipe products required by Lukoil for use in all stages of oil production and refining. The supply volumes are planned to be at least 260000 tonnes per year.

Lukoil is among the most significant customers of TMK's products. In 2011, TMK supplied the oil company with more than 130000 tonnes of pipe.

\section{Broner provides Integrated Scheduling solution to CSN}

Broner has been selected by CSN (Compania Siderurgica Nacional, Brazil) to implement a new caster and hot mill scheduling solution for integration with existing planning and scheduling modules.

In 2010, Broner conducted a benefits study at CSN to identify areas for improvement. The study revealed potential savings by improving slab reallocation and reducing the quantity of tundishes used, improving synchronization problems due to breaks in sequences in the melt shop, and reducing the time between slabs released out of the furnace in the hot strip mill. 
The new project consists of integrating Broner's caster scheduler (CS), hot mill scheduler (HS) and melt shop control centre (MSCC) modules to work together to generate synchronized schedules. This must aim to achieve up to $30 \%$ hot connect, dependent upon manufacturing conditions and the content of the order book.

The scheduling process at CSN has been designed to be easily configured to reflect the bottleneck processes:

- hot mill driven - subordinate casting and steel making to optimise re-heating and rolling;

- caster driven - optimise caster productivity and subordinate rolling and steel making;

- steel plant - optimise use of hot metal.

\section{Siemens VAI Metals Technologies launches new EAF}

Siemens VAI Metals Technologies offers steelworks operators an electric arc furnace that has been specially developed for the use of DRI (direct reduced iron). The Simetal EAF FAST DRI is designed for a continuous melting process as electrical energy input and DRI are supplied during tapping. The furnace has a tiltable lower vessel with an extensive liquid heel. The resulting continuous flat-bath operation allows electrical energy input and DRI feeding during tapping.

Thanks to the patented furnace advanced slag-free tapping system (FAST), charging, tapping and taphole refilling are possible under power-on conditions. Compared with conventional arc furnaces, tap-

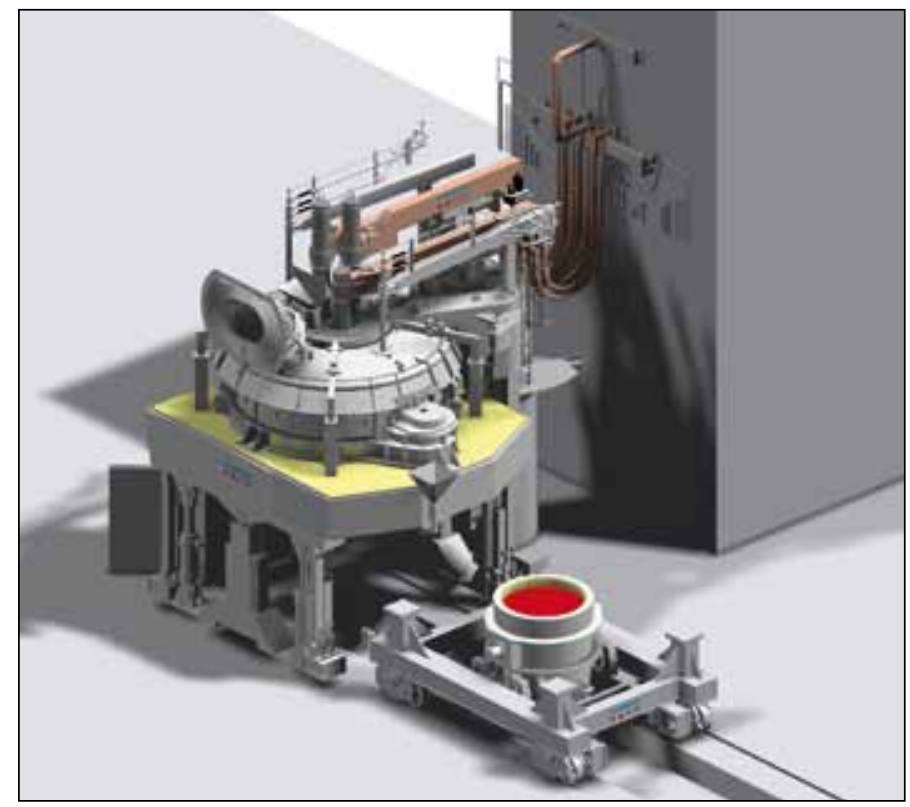

The new arc furnace was specially designed for the use of direct reduced iron. to-tap times can be reduced by up to $15 \%$. Energy consumption is cut by 20 kilowatt-hours per ton and electrode consumption falls by $10 \%$. The continuous supply of electrical energy during flat-bath operation improves productivity and avoids line harmonic distortions such as flicker.

The continuous operation of the furnace offers a number of other benefits. Coal and oxygen injection as well as foaming slag control can be implemented even more precisely. Slag-free tapping results in an enhanced alloys yield and better steel desulfurization. Installation of additional burners thus becomes superfluous. Thermal stress on the refractory and structure materials also remains constant, prolonging their useful lives.

The Simetal EAF FAST DRI is designed so that, in combination with the hot transport system (HTS) from Siemens, it can also be fed with hot $\mathrm{DRI}$ at temperatures of around $600{ }^{\circ} \mathrm{C}$. Thanks to the modular design of the new electric arc furnace, existing furnace installations can also be retrofitted with FAST DRI technology.

\section{Severstal North America commissions new hot dip galvanizing line}

Steel producer Severstal North America, announced its new hot dip galvanizing line (HDGL) located in Dearborn, Mich., has begun production of galvanized products. This will enable SNA to supply the Detroit (Michigan, USA) area, where, in particular, the Ford headquarters are located.

"This new facility strengthens our presence in the automotive industry with highly demanded galvanized and galvanneal products for internal and external parts of automobiles", said Sergei Kuznetsov, Chief Executive Officer, Severstal North America. The new HDGL includes controls for coating thickness and surface texture, as well as alloy and phase control. The 285 million \$ HDGL project completion follows the August start-up of Severstal Dearborn's pickle line tandem cold mill (PLTCM). The HDGL and PLTCM facilities are part of Severstal's modernization program, which aims at expanding its finishing capabilities.

The line is capable of producing 500000 tons of exposed hot-dipped galvanized (HDGI) and exposed hot-dipped galvanneal (HDGA) steel. These capabilities are used to manufacture steel products including highly formable interstitial-free steels for customers in the exposed automotive, appliance, and furniture industries, as well as precision automotive products, including high-strength and advanced high strength steels. The process equipment for the new line was supplied by CMI Metallurgy. JNE Consultants provided the facility engineering, while Barton Malow Company provided the construction services, overseeing the project installation. 


\section{= Ellwood National Steel orders VOD facility from SMS Siemag}

SMS Siemag LLC, Pittsburgh, PA has received an order for the supply of a VOD facility (vacuum oxygen decarburizing) from Ellwood National Steel in Irvine, Pennsylvania. The project is undertaken to enable the production of low-carbon stainless steel forgings with a demanding combination of strength, toughness and corrosion resistance. This unit will be equipped with a mechanical vacuum pump rather than a steam ejector system with a boiler. This will be the first VOD unit in the U.S.A. with mechanical vacuum pumps, including gas cooler and bag filter system to reduce the environmental impact. The scope of supply is comprised of the mechanical process equipment, complete with an alloy addition system. Also the entire electrical and automation systems will be provided, including the latest level-1 and level-2 control technologies. SMS Mevac, Germany, as the center of competence for VOD technology within the SMS group, will be providing process know-how, training and basic engineering based on a license agreement with a leading German stainless steel producer. SMS Mevac will be closely involved in the entire project execution. Start of production is planned for December 2012.

\section{Vallier and MC2 Chimie create Inustry}

Vallier and MC2 Chimie (Vallier Group) have decided to mutualize their expertises, and subsequently create the brand 'Inustry'. Inustry's range of products and services includes technical fluids (oil, solvents, lubricants, desgreasing, rustproofing, washings, special fluids, etc.), related techni

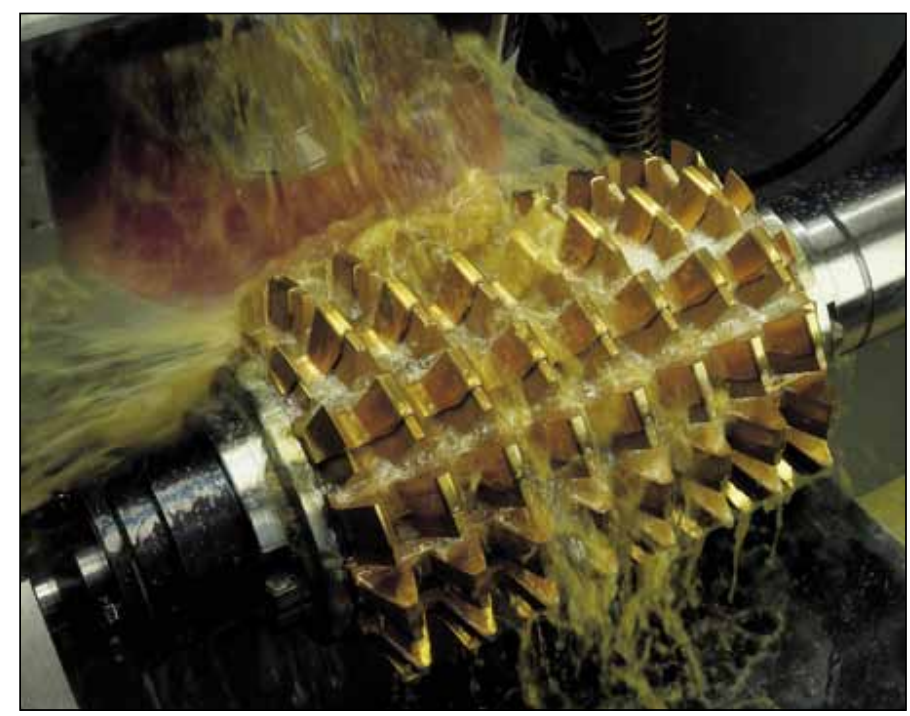

Inustry's offering includes fluids, and related services. cal assistance, and management of toxic industrial waste. Vallier and MC2 Chimie have developed close partnerships with industrial fluid suppliers (Dow, Henkel, Total, Shell, Safechem, Houghton, Ineos, Arkema, Rhodia, etc.), and offer a range of in-house developed solvents (Dercam). Inustry's expertise and products are already being implemented by customers such as Arcelor-Mittal and Montupet Foundry.

\section{SMS Siemag supplies second production line at Severstal Columbus}

SMS Siemag, Germany, supplied a second production line at Severstal Columbus, USA, comprising an electric steel plant and a second CSP caster. SMS Siemag also erected a new push-pull pickling line for downstream processing of the strips. The commissioning of the second production line enables the company to supply the market with 2.7 million tpy of highgrade steel. The production embraces among others autobody sheet and high strength steels for the automotive industry, API grades for the pipe and tube industry and deep-drawing steels for suitable areas of application. On the CSP plant, Severstal produces hot strip in widths from 900 to $1.880 \mathrm{~mm}$ and gages from 1.3 to $12.7 \mathrm{~mm}$.

SMS Siemag supplied the complete X-Pact electrical and automation package for the CSP facility. The supply scope comprised the level-1 automation system including the technological control systems and level-2 automation with the process models and an HMI (human machine interface) for operation of the plant. For downstream processing of the strips, SMS Siemag built a new push-pull pickling line, which processed the first coil in mid-November 2011. The line is used for uncoiling, leveling,

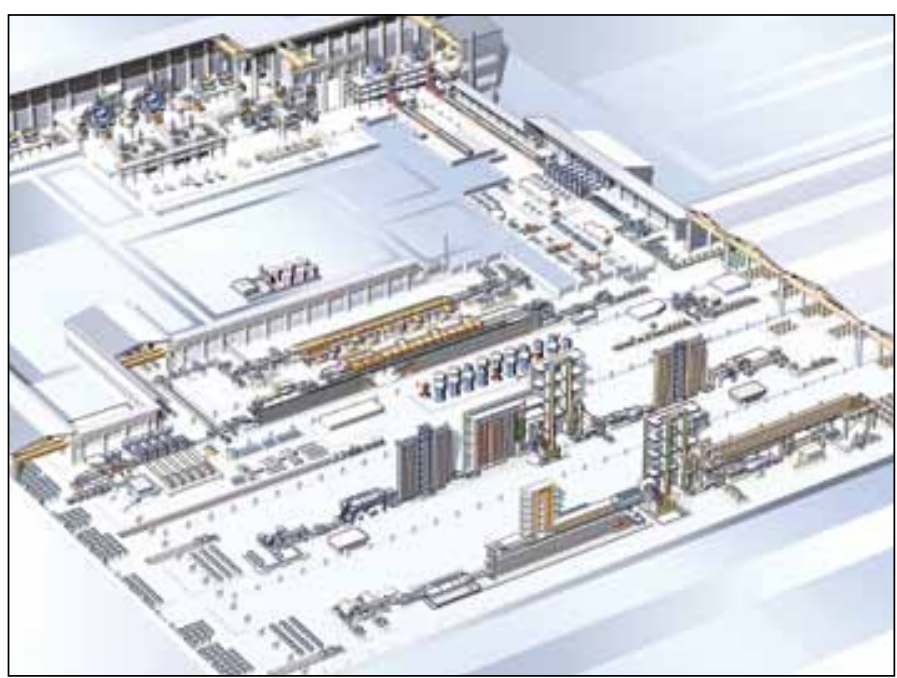

SMS Siemag's scope of supply includes an electric steel plant, a second CSP caster and a new push-pull pickling line. 
pickling, side trimming and recoiling the hot strip. A special feature of the 540 000-tpy line is that the turbulence pickling section is equipped with plastic tanks. Furthermore, SMS Siemag installed a hot-dip galvanizing line with a horizontal furnace. The annual capacity of the line is 544000 tons.

\section{Tenova Re Energy to supply EAF to Feralpi Siderurgica}

Tenova Re Energy, which specializes in engineering and construction of heat recovery systems, has signed a contract with Feralpi Siderurgica to supply an EAF iRecovery system for its German plant Elbe Stahlwerke Feralpi $\mathrm{GmbH}$, Riesa, Germany. "Up to $20 \mathrm{MW}$ from the off gas of the existing EAF will be recovered", explains Ralf Granderath, CEO of Tenova Re Energy. The recovered energy is converted into steam, which is partly sold to a local energy carrier and partly led to an ORC turbine generating $2.5 \mathrm{MW}$ electrical energy. iRecovery system is part of the iSteel solution package. The iRecovery plant in Elbe Stahlwerke Feralpi $\mathrm{GmbH}$, Riesa will be commissioned early 2013.

\section{ThyssenKrupp modernizes blast furnace 9 in Duisburg}

Blast furnace 9 at ThyssenKrupp Steel Europe in Duisburg-Hamborn has been shut down for a period of 180 days to allow the refractory lining and parts of the cooling system to be replaced. The steel producer is investing 37 million $€$ in this modernization project, which must improve the competitiveness and sustainability of the site.

During the shutdown of blast furnace 9 , the other three blast furnaces furnaces 1 and 2 in Schwelgern which have more than double the capacity, as well as furnace 8 - will run at full capacity to ensure hot end operations.

The Hamborn blast furnace operations of ThyssenKrupp Steel Europe with furnaces 8 and 9 produce roughly 3.7 million tons of hot metal per year, which is processed into crude steel in the melt shops. Iron oxide-bearing ores are reduced with coke and coal dust in the blast furnaces to form hot metal. Originally built in 1962, blast furnace 9 was completely revamped and enlarged in 1987, since when it has produced around 40 million tons of hot metal. The furnace, which has an annual capacity of 1.7 million tons, would have been due for a complete reline in two years at the latest, as its current campaign, i.e. the period until the roughly two meter thick refractory lining needs to be fully replaced, was close to the end.

Roughly 2.400 tons of refractory material is needed for the new lining 1.900 tons for the hearth and 500 tons for the shaft area. In a second phase of the relining project, a modern dust extraction system with a fabric filter

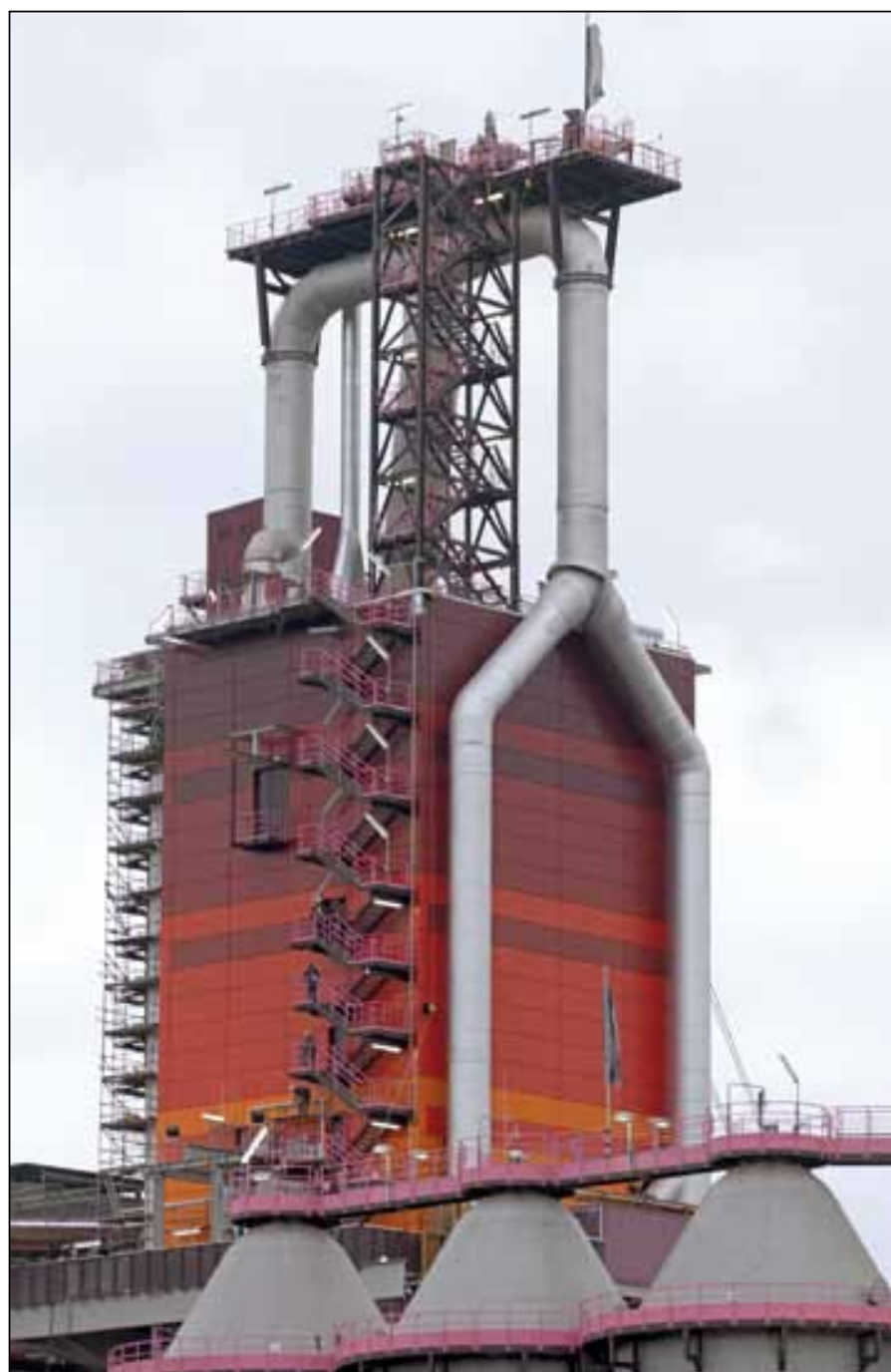

Blast furnace 9 will then be given a color cladding so as to match its twin BF 8 .

will be fitted at a later date - initially during ongoing operations - which will help further reduce dust emissions. After that, the casthouse will be modernized and a new inclined elevator installed. In addition, blast furnace 9 will then be given an attractive color cladding so as to match its twin, blast furnace 8 , which was built a few years ago (start of production December 2007).

\section{Ma'aden Alcoa aluminum joint venture pours first concrete at Ras al Khair}

The Ma'aden Alcoa aluminum joint venture has poured the first concrete in the construction of the region's first alumina refinery at the fully 
integrated aluminum complex at Ras AI Khair, Saudi Arabia. Once complete, the refinery will initially produce 1.8 million tons of smelter-grade alumina per year.

In its initial phases, the joint venture will develop an integrated industrial complex which comprises:

- A bauxite mine with an initial capacity of 4000000 tons per year,

- An alumina refinery with an initial capacity of 1800000 tons per year,

- An aluminum smelter with an initial capacity of 740000 tons per year,

- A rolling mill, with initial capacity of 380000 tons per year. The mill will be the first in the Middle East and will be one of the most technically advanced mills in the world.

The complex's smelter and rolling mill are scheduled to begin commercial production in 2013. The mine and refinery will follow in 2014. Alcoa will supply alumina to the smelter in the interim period.

\section{Metinvest to invest in Mariupol-based steel works}

Metinvest intends to invest around 8 billion $\$$ till 2020 into the reconstruction and modernization of its two integrated steel works in Mariupol - Azovstal and Ilyich Iron and Steel Works of Mariupol (Ilyich Steel), and increase the crude steel output by $35 \%$ to 16 million tons. Simultaneously, the company considers reducing gross emissions by 3.5 times and specific emissions per tonne of steel by 5 times. "We are determined to provide substantial reduction of negative exposure on environment while modernizing our facilities to improve production efficiency, said Igor Syry, Metinvest's CEO. The measures to be realized in 2012 will have emissions reduced by $10 \%$ ".

\section{Ruukki to increase laser cutting capacity}

Ruukki has acquired a second bevel laser cutting line for its service centre in Seinäjoki, Finland. Deployment of the new line is in response to increased demand for prefabrication services. The new bevel laser cutting line can process steel up to $20 \mathrm{~mm}$ thick and 12 metre long and can process both Ruukki's special steels and standard steels.

"The new laser will enable us to respond to the increasingly demanding quality criteria required by, for example, in parts for automatic welding. Deployment of the new line will improve our possibilities to offer customers competitive and cost-effective services. Prefabrication services that improve the efficiency of the manufacturing process are in great demand,

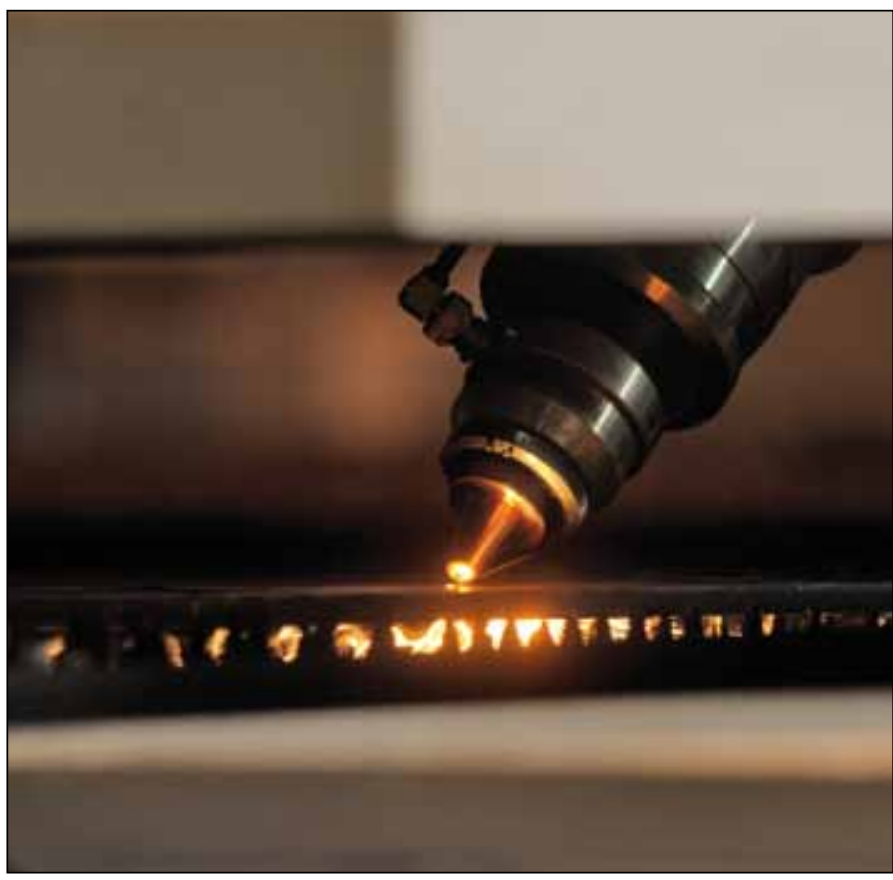

Ruukki's new bevel laser cutting line will be in productive use in May 2012.

which is why we continue to develop them further", Pekka Oja, VP, Finland and Baltics at Ruukki Metals.

The new bevel laser will be in productive use in May 2012. Because the new line is being housed in the existing production facilities in Seinäjoki and expertise in the use of a similar laser already exists, the laser will soon be fully up and running after installation.

\section{Interpipe's Dneprosteel smelting complex completes testing}

Interpipe and Italian general contractor Danieli have completed hot testing of the manufacturing equipment at the Dneprosteel Electric Steel Smelting Complex (ESSC, Dnepropetrovsk, Ukraine). The hot testing was carried out on the entire production chain of ESSC including arc steel-smelting furnace, ladle furnace unit, steel vacuum degassing unit, and continuous casting machines $\mathrm{N}^{\circ} 1$ and $\mathrm{N}^{\circ} 2$. During the first melting process 100 tons of steel billets were produced, and further processed at Interpipe NTRP seamless pipes plant.

The list of consumers of Dniprosteel pipe billets will include two Company's plants - Interpipe NTRP (city of Dnipropetrovs'k) and Interpipe Niko Tube (city of Nikopol). At present both enterprises are ready for integration with the Dniprosteel electric steel-smelting complex. 


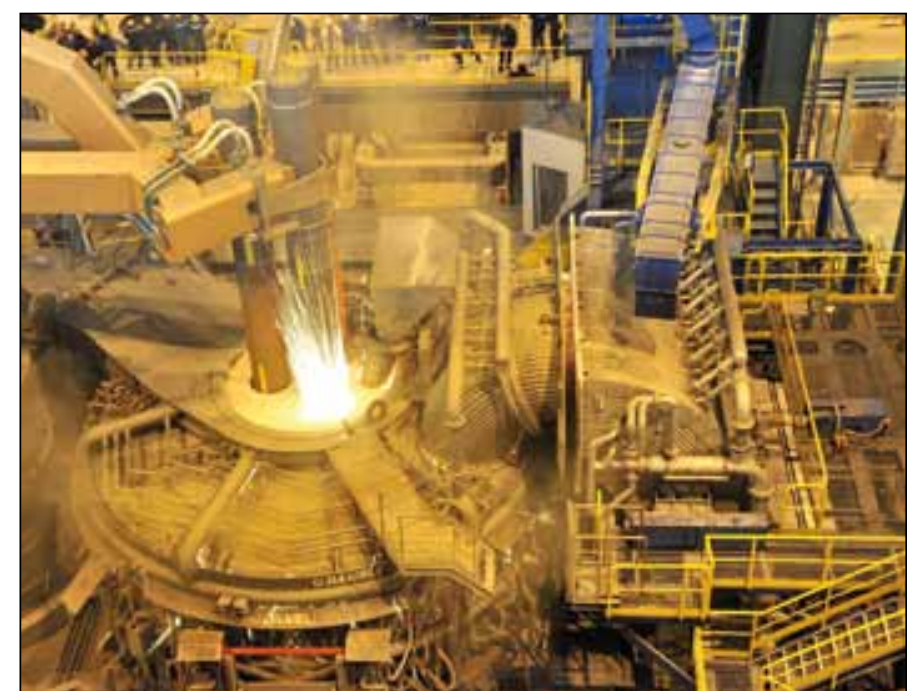

The hot testing was carried out on the arc steel-smelting furnace, ladle furnace unit, steel vacuum degassing unit, and continuous casting machines.

"One of the major reasons for Dniprosteel construction is to ensure the provision of Company's plants with our own billets for seamless pipes and railway wheels. Interpipe currently purchases $70 \%$ of steel billets for seamless pipes from external suppliers. When Dniprosteel reaches its full capacity in 2014, Interpipe's self-sufficiency in billets for production of seamless pipes will state for $90 \%$ ", says Alexander Kirichko, Interpipe General Manager. The completion of the Dniprosteel hot and performance testing are scheduled for the end of the 1st quarter of 2012, and after that there will be the official commissioning of the plant. The planned production volume for 2012 is approximately 700 thousand tons of steel billets for pipes and wheels.

The rolling of the first pipe was carried out by one of the Interpipe NTRP shops, producing oil and gas pipes. Twelve billets with the weight of 100 tons were cut into ingots for production of casings (pipes used for oil and gas extraction). The rolling process resulted in 94 pipes with the length of 12 meters each.

\section{Industry to supply a new continuous annealing line to Shagang Group}

CMI Industry signed a contract with Shagang Zhangjiagang Yangzi River Cold Rolled Sheet Co. Ltd. (Shagang Group) for the design and supply of a new annealing line. This project involves all CMI Industry technology centers (CMI Processing Lines, CMIThermline, CMI Greenline, CMI Chemline and CMI Rolling Mills). The line is scheduled to come into operation in August 2013.
This new annealing line will handle cold rolled low carbon steel, ultralow carbon steel (IF steel) and high strength steel. The finished product will be used for high level construction appliances and for the automotive industry. The line will be installed in Shagang's cold rolling complex number 1 (Zhangjiagang, Juangsu province, China). This complex is capable of producing two million tons of $1420 \mathrm{~mm}$ cold rolled steel per year.

\section{Tyasa orders compact plant from - Siemens VAI Metals Technologies}

Siemens VAI Metals Technologies has received an order from Talleres y Aceros S.A. de C.V. (Tyasa), a Mexican steelmaker, to supply a new compact steelmaking plant with a capacity of 1.2 million tons of steel per annum for its Ixtaczoquitlan site.

Siemens will supply a quantum electric arc furnace with a tapping weight of 100 tons, as well as secondary steelmaking facilities. These include a 100 ton double ladle furnace and a 100 ton double vacuum degassing plant.

The plant will have a capacity of around 1.2 million tons of killed, low, medium and high-carbon steels per annum. The steel it produces will be cast in a six-strand combination continuous caster into billets with crosssections ranging from $130 \times 130$ millimeters to $200 \times 200$ millimeters, as well as rough profiles with dimensions of $300 \times 200 \times 80$ millimeters. The new plant will enable Tyasa to widen its range of products.

The key component of the compact steelmaking plant is the Simetal EAF Quantum electric arc furnace newly developed by Siemens. This combines proven shaft furnace technology elements with a new scrap charging process, an efficient preheating system, a new tilting concept for the lower shell, and an optimized tapping system. This enables tap-totap times of 36 minutes to be achieved. The electricity consumption, at 280 kilowatt-hours per ton, is lower than that of a conventional electric arc furnace. This, coupled with the lower consumption of electrodes and oxygen, gives a total advantage in the specific conversion cost of around $20 \%$. Total CO2 emissions can also be reduced by up to $30 \%$ per ton of crude steel in comparison to conventional electric arc furnaces.

A dry dedusting system with evaporation cooler, a quenching tower, an automated pulse-jet-type filter-bag house and an induced draught fan will be installed in order to minimize the emissions of the steel works. The dedusting system will clean the offgases from the electric arc and ladle furnaces, as well as from the material handling system. The dedusting system will have a cleaning capacity of around one million cubic meters per hour, and reduce the dust content of the offgases to less than ten milligrams per cubic meter. 


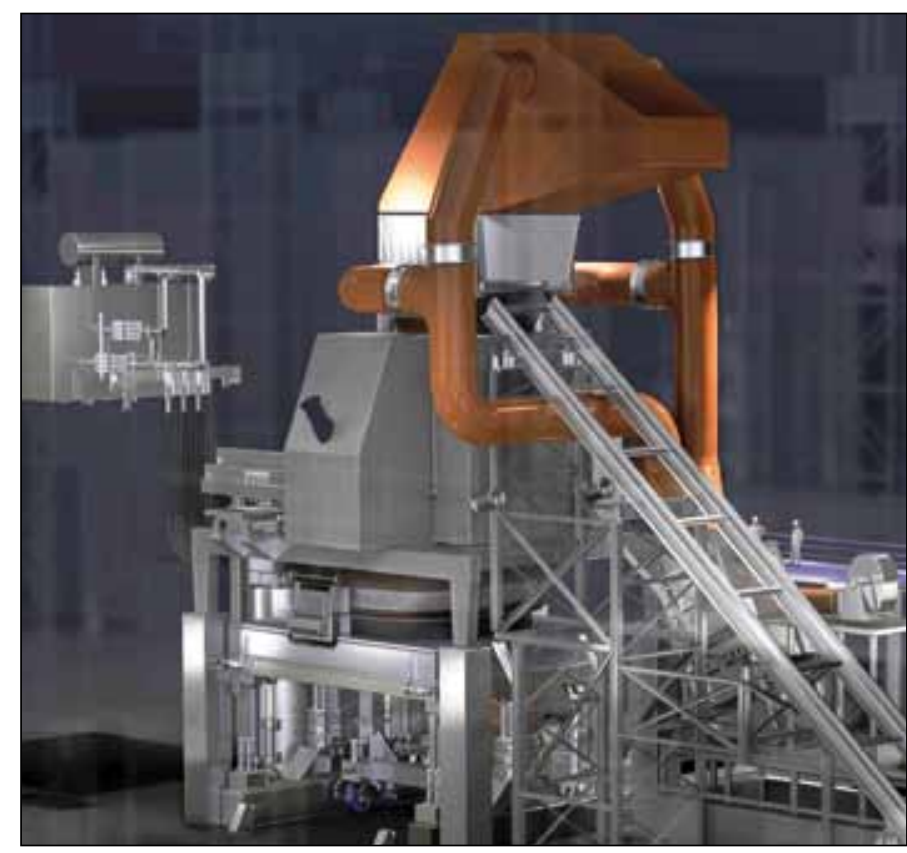

The world's first Quantum electric arc furnace is being constructed for Talleres y Aceros S.A. de C.V. (Tyasa), a Mexican steelmaker.

The project also includes a double circuit water cooling system for the electric arc furnace, the secondary steelmaking facilities and the casting plant. Drinking, process and extinguishing water circuits will also be installed. It is also planned to construct a water treatment plant with mechanical and chemical stages. This will enable the total water requirements of the steel works to be optimized.

The scope of supply from Siemens is rounded off by electrical and automation systems and components. These include the power distribution, the basic and process automation, as well as process models for the steel works and the continuous caster.

Talleres y Aceros S.A. de C.V. was founded in 1985, and is privately owned. The company currently has two production sites, one in Ixtaczoquitlan near Orizaba in the State of Veracruz, the other in Mérida, the capital city of the Mexican State of Yucatán. Tyasa produces around 450000 tons of billets per annum, which are then further processed in its own rolling mill to make wire and bar steels, as well as building materials, such as rebars and nails. The total capacity for rolled products is around 700000 tons per annum.

\section{Essar Steel completes capacity expansion at Hazira}

Essar Projects India Limited (EPIL) has announced the handing over of the $5 \mathrm{mtpy}$ steel plant to Essar Steel. The completion of this project makes the Hazira steel complex in Gujarat, with an annual capacity of $10 \mathrm{mtpy}$, the largest single location flat steel producer in India and the fourth largest single location flat steel producer globally. This has been completed at a total cost of 5.7 billion $€$.

In order to support the steel plant, Essar Projects has built associated facilities in Hazira that include a 30 mtpy all-weather port, two power plants with an annual capacity of $1015 \mathrm{MW}$, oxygen and lime plants, a fabrication facility, and a self contained township. In addition, Essar has invested in an $18 \mathrm{mtpy}$ refinery, $1.5 \mathrm{mtpy}$ plate mill, $0.6 \mathrm{mtpy}$ pipe mill, $1600 \mathrm{MW}$ power projects, 88 mtpy port facilities and a township in Jamnagar in Gujarat, taking the total projects executed in Gujarat alone to over 13.8 billion $€$.

The complex will provide steel to meet the diverse needs of various industries, while also making the Hazira steel complex a national hub for Essar Steel to provide a range of steel products to the rest of the country.

\section{PEOPLE AND ORGANISATION}

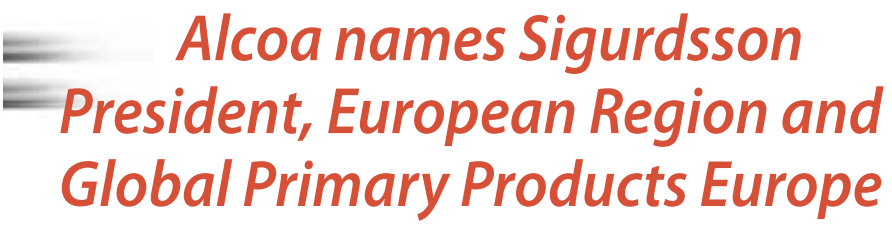

Tómas Már Sigurdsson, Managing Director Alcoa Fjardaál, has been appointed President, European Region and Alcoa Global Primary Products (GPP) Europe. Sigurdsson succeeds Marcos Ramos who has assumed new responsibilities as President of GPP in Latin America and the Caribbean.

As European Regional President, Sigurdsson will be responsible for coordinating the activities of all of Alcoa's nearly 50 locations throughout Europe, reporting to Chris Ayers, Alcoa Executive Vice President and President, Alcoa Global Primary Products, who is overseeing Europe as a member of Alcoa's Executive Council.

Sigurdsson joined Alcoa in March 2004 from Nordurál, a primary aluminum manufacturer in Iceland, where he held various management positions since 1997. Early in his career he was an engineer/project manager for Hönnun Ltd. Consulting Engineers and the Icelandic Public Road Administration. A graduate of the University of Iceland, Reykjavík, Sigurdsson has a bachelor's degree in Civil and Environmental Engineering and a master's degree in Development Planning in 1995 from Cornell University, in the United States. 